\title{
Symbolization as a way of art completion \\ in the story by A. Eniki «Unvoiced testament»
}

\section{[Символизация как способ художественного завершения в повести А. Еники «Невысказанное завещание»]}

\author{
Venera R. Amineva
}

\section{DOI: 10.18355/XL.2017.10.01.02}

\begin{abstract}
Аннотация
На материале повести татарского прозаика А. Еники (1909-2000) «Невысказанное завещание» определяются характерные для творческого метода писателя принципы и приемы символического обобщения, основанные на взаимодействии фабульно-психологических и лирико-философских начал в произведении. Они опираются не на идею двоемирия, а на осмысление современной писателю действительности как кризисного этапа национальной истории. Устанавливаются семантическая структура наиболее значимых символических образов в произведении: «домашнего очага», «степи» и «родной земли», их функции и место в художественной системе целого. Охарактеризованы приемы символизации главных героев (Акэби, поэта). Сделан вывод о том, что принципы символической типизации обогащают возможности реалистического изображения действительности, характеризуя одну из важнейших тенденций национального историко-литературного процесса.
\end{abstract}

Ключевые слова: татарская литература, символ, образ, мотив, герой, деталь, идентичность

\section{Введение}

В повести А. Еники «Невысказанное завещание» (1965) принципы реалистического изображения действительности (различные формы детерминизма, социально-бытовая типизация героев и их индивидуализация и др.) соединяются с поэтикой, характерной для нереалистических художественных форм, значительное место занимают устойчивые структурносемантические комплексы, эмпирическое содержание образов и сюжета расширяется и углубляется символическим подтекстом.

В исследованиях, посвященных творчеству А. Еники, содержатся отдельные наблюдения, касающиеся семантической структуры символических образов и мотивов в произведениях писателя. Так, Ф.М. Хатипов и P.Х. Сверигин обращают внимание на роль образа медного колокольчика в организации художественного времени в «хикая ${ }^{1}$-воспоминании» «Медный колокольчик» (1966): этот «атрибут повседневной жизни становится в произведении связующим звеном между прошлым и настоящим» (Khatipov, Sverigin, 2009: 35). По мнению Д.Ф. Загидуллиной, образ гор в хикая «Глядя на горы» (1948) символизирует такие ценности жизни, как род, преемственность, любовь (Zagidullina, 2015: 191-192).

${ }^{1}$ «Хикая» в переводе с татарского - рассказ, повествование.

12 
Особое внимание ученых привлекает символическое содержание персонажей и предметных деталей в повести «Невысказанное завещание» (1965). Д.Ф. Загидуллина указывает на обилие символических образов-деталей, выражающих душевную боль автора: Акэби - знак душевной чистоты, степь жизнь, очаг - символ духовных богатств, устойчивого образа жизни, уходящего корнями вглубь веков, завещание - связь между поколениями (Zagidullina, 2015: 199). Ф.М. Хатипов и Р.Х. Сверигин выявляют символическое значение кольцевой композиции произведения (Khatipov, Sverigin, 2009: 29). М.И. Ибрагимов считает образ главной героини знаковым для татарской литературы XX века: «Этот образ стал своего рода национальным литературным типом, сущность которого состоит в сохранении национальных традиций, веры, нравственных устоев» (Ibragimov, 2003: 35).

Дальнейшее углубление представлений о природе художественного мышления писателя и свойственных ему принципах типизации требует исследования их идейно-философских предпосылок, способов создания и поэтики символических образов, их функций и места в художественной системе целого. Не претендуя на исчерпывающее решение этих вопросов, рассмотрим их отдельные аспекты на примере повести «Невысказанное завещание» знакового в творчестве писателя 1960-х гг. произведения, одного из ключевых текстов татарской литературы этого периода.

Способы символообразования соотносятся с параметрами индивидуально-авторского художественного сознания, особенностями мироощущения писателя, его творческими принципами. В то же время природа и функции устойчивых структурно-семантических комплексов раскрывают глубинные механизмы, определяющие универсальные и уникальные свойства каждой национальной литературы. Этим определяется актуальность проводимого исследования. В конце XX - начале XXI вв. проблема литературной идентичности относится к числу активно обсуждаемых и дискуссионных (Identité littéraire de l'Europe, 2000; Škulj, 2003; Douglas, 2007; Davidson, 2013; Amineva, 2014; Amineva, 2015; Zagidullina, Amineva, 2016).

\section{Методика}

Методологическую базу исследования составили работы, посвященные символу как философско-гносеологической категории (см.: Rosse, 1962; Losev, 1976; Waardenburg, 1980; Svas'ian, 1980; Storr, 1987; Averintsev, 2001; др.) и категории поэтики художественного текста (Johnson, 1982; Skorupski, 1983; Lotman, 1996; Toporov, 1996; Saiapova, 2006).

В литературоведении установлено, что природа символа как структурированного художественного пространства в восточных культурах иная, чем в русской и западноевропейской (см.: Smirnov, 2001; Shukurov, 1989). Логика смыслопорождения, присущая арабо-мусульманской культуре, определяет основную форму манифестации символа как знака: «Принципиальной нетождественности, разведенности в символе плана выражения и плана содержания, их столкновению, взаимоотрицанию и взаимопереходу здесь (в произведениях восточных авторов - В.А.) соответствует равнозначность и равноценность образующих оппозиции категорий: вариативная репрезентация исходного «пре-текста» оказывается не менее важной, чем его внутреннее семантическое ядро» (Amineva, 2010: 109).

На концепцию проводимого исследования оказали влияние труды, посвященные проблемам идентичности национальных художественноэстетических систем, обоснованию их самобытности (Kristeva, 1980; Waardenburg, 1980; Miner, 1990; Chinese Texts and Philosophical Contexts. 1991; World Philosophy, 1995; Lacan, 1998; G.Tukay's poetry, 2015). Также 
востребованными для решения поставленных задач стали межкультурные подходы, результативность которых выявлена в работах Я. Бировой (Birova, 2013, 2; Birova, 2013, 3).

\section{Символизация}

А. Еники не свойственен метафизический дуализм феноменального и ноуменального, Он стремится запечатлеть многомерность и неоднозначность жизненных явлений, осмыслить их с точки зрения универсального и вечного. Д.Ф. Загидуллина обращает внимание на то, что А. Еники возрождает характерное для татарской литературы начала XX века качество - синкретизм философской и художественной мысли (Zagidullina, 2015: 187). В основе художественного подхода писателя к действительности - измерение ее критериями общечеловеческих и национальных нравственных ценностей. За эмпирической реальностью общественной и частной жизни людей, ее социальной и психологической детерминированностью в прозе писателя просматриваются экзистенциальный сюжет и связанный с ним глубинный философско-метафизический план повествования. В таких произведениях, как «Марево» (1962), «Совесть» (1968), «Успокоение» (1978) и др., начинается диалог писателя с современниками по широкому кругу актуальных проблем - о совести и добре, их искажениях в человеке, об утрате корней, памяти и беспамятстве в общественном сознании, о подмене подлинных ценностей мнимыми.

Повесть «Невысказанное завещание» А. Еники синтезирует в себе несколько жанровых стратегий. Пространные внутренние монологи героини и замещенная прямая речь содержат в себе элементы молитвенного дискурса, с которым взаимодействует другой жанрово-стилевой поток - дидактическинравоучительный, генетически восходящий к традиции насихатов ${ }^{2}$ и к концепции «адаба», являющегося неотъемлемой частью мудрости и справедливости и определяющего систему исламского воспитания (см.: Daud, 2000: 265).

Произведение начинается описанием широкой башкирской степи, светлой и печальной, с волнами колышущегося на ветру ковыля: «Дует легкий ветерок... Стелется, несется ковыль. Потряхивая шелковистыми метелками, с тихим шуршанием мчится вперед, суетливо и озабоченно, будто боясь опоздать куда-то... Не оторвать взгляда...» ${ }^{3}$ (Enikeev, 1974: 137). Величественнопространственная, развернутая в ширь эпическая картина символизирует широту национального самосознания. В финале повторяется образ степи со свойственными ему мотивами бесконечного движения: «Мчится, несется по степи ковыль...» (Enikeev, 1974: 175). Степь выполняет миромоделирующую функцию в повести. Это пространство традиционности, неизменности установленного уклада жизни.

Во вступлении эпические структуры поглощаются лирической ориентацией повествования, которая определяется ритмико-мелодической организацией речи, образно-метафорическим характером лексики, подчеркнуто экспрессивным строением фраз: «Не оторвать взгляда... Эх, уйти бы за седым ковылем далеко-далеко по необозримой пустынной степи. Земля под ногами теплая и ласковая, резвый ветерок треплет по лицу, покой и умиротворение

\footnotetext{
${ }^{2}$ Насихат (с араб. - «назидание», «наставление», «нравоучение») - «в средневековой персидской и тюрко-татарской литературах поэтическое, прозаическое или смешанное произведение дидактического содержания. В афористической, образной форме читателю даются совет, наставление назидание» (Tatarskaia entsiklopediia, 2008: 368).

${ }^{3}$ Перевод повести на русский язык выполнен Х. Хусаиновой.
}

14

XLinguae Journal, Volume 10 Issue 1, January 2017, ISSN 1337-8384 
проникают в душу. Здесь так хорошо!.. И грустно. Почему-то грустно. Оттого, может быть, набегавшись вволю по бескрайней, молчаливой башкирской степи, хочется припасть к земле и выплакать эту непрошеную грусть-печаль...» (Enikeev, 1974: 137). Безграничность степного простора рождает особое переживание, которое состоит из нюансов противоположной эмоциональной тональности и заключает в себе единство радости и печали. Набегавшись, припасть к земле и разрыдаться - действия, обозначающие переход из одного состояния в другое. Так достигается эффект отрешения от земной суеты и приобщение к вечному, абсолютному бытию, осознание своей слитности с миром, Вселенной. В этом фрагменте, воспринимаемом как авторский текст, образ степи приобретает универсально-философский смысл и символическое звучание.

К природно-вневременным первоосновам народно-национального бытия наряду с повествователем причастны два героя повести - Акэби ${ }^{4}$ и старик Миннибай. Акэби, как отмечает повествователь, любила степь, и впервые мы видим ее собирающей кизяк, который по давнему обычаю в степных аулах использовался в качестве топлива. Другой герой, жизнь которого неотделима от степи, - это дед Миннибай. Его единственное и неизменное занятие - ходить по степи, которую он знает, «как свои пять пальцев». Каждый день старик Миннибай выходит в поле и, не выбирая дороги, идет наугад. Обойдя обширные поля, он иногда возвращается домой с другого конца аула. Это движение по кругу, как и кольцевая композиция повести, соотносятся с циклической концепцией времени - круговоротом времен года, жизни и смерти, сменой человеческих поколений.

Динамичное пространство степи дополняется и в начале, и в конце произведения образом домашнего очага с соответствующими ему темами «тепла» и «света», с которыми связаны представления о покое, уюте, любви, счастье, семейных связях. Миннибай, встретив Акэби в степи и узнав, что она ходила собирать кизяк, говорит: «Ну-ну... хорошо, когда огонь в очаге не гаснет» (Enikeev, 1974: 139). В конце повести Миннибай, проходя мимо дома покойной Акэби, спрашивает ее соседку Гарифе, не вернулась ли Акбикэкилен $^{5}$, и просит поддерживать огонь в ее очаге. «Аккилен не умерла, она только уехала... Уехала... Даст бог, вернется, вернется она домой... Ты поглядывай за ее очагом... Чтобы не затух огонек...» (Enikeev, 1974: 176) 6 .

Почему старейшина деревни дед Миннибай придает такое большое значение тому, чтобы огонь не угасал в домашнем очаге? По мнению Ф.М. Хатипова и Р.Х. Сверигина речь идет о том, чтобы не угасал одухотворяющий традиции поэтический огонь (см.: Khatipov, Sverigin, 2009: 30). Исследователями традиционной культуры тюркских народов

\footnotetext{
${ }^{4}$ Акэби - буквально: «белая бабушка».

${ }^{5}$ Килен - обращение к младшей снохе, жене сына, невестке. Семидесятилетняя старушка была для старейшины деревни деда Миннибая все еще «килен». Так звал ее только он один, для других она давно уже стала Акэби.

${ }_{6}^{6}$ М.И. Ибрагимов, анализируя этот эпизод, обращает внимание на семантику мотива возвращения. «Этот мотив, с одной стороны, восходит к существующему в исламской традиции представлению о бессмертии души, которое чаще понимается как «возвращение» (Efremova, 2001). С другой стороны, мотив «возвращения» восходит к мифопоэтической традиции, в которой особое место занимают мифы о временной смерти и последующем воскресении. Подобного рода календарные мифы, получившие распространение в мифологии аграрных народов, воспроизводят представления о цикличности природных процессов (Meletinskii, 2000: 218-222). Возникающий в конце повести образ циклического времени связан с надеждами автора на возрождение нации» (Ibragimov, 2003: 37).
} 
П.К. Дашковским и С.М. Карымовой установлено, что «если на макрокосмическом уровне вертикаль, связывающая все уровни бытия, представлена в виде оси (дерева, горы, столпа), то на уровне микрокосма - в жилище - она обозначена центральным положением очага и отверстием в центре верхней части жилища» (Dashkovskii, Karymova, 2012: 103). Таким образом, домашний очаг как одно из материальных воплощений центра мира имел сакральное значение 7 . Священным считался и огонь в очаге, воплощающий идею одухотворенности пространства дома ${ }^{8}$. Убеждение Миннибая в том, что Акбикэ-килен не умерла и должна обязательно вернуться, связано, на наш взгляд, не столько с верой в возвращение душ, сколько с тем, что для него, столетнего странника, Акбикэ-килен действительно жива, поскольку нет строгого разграничения на мир «тот» и «этот», потусторонний и посюсторонний . Ассоциативная связь, которая объединяет символический подтекст завязки и финала, обнажает родовые категории человеческого существования, которые проецируются на психологические и бытовые реалии сюжета, наполняя их универсальным содержанием.

Старик Миннибай за свою долгую жизнь видел много изменений, которым не успевал удивляться. Однако поток сменяющих друг друга событий все же не оставляет его безучастным. Он живо реагирует на те симптомы нового времени, в которых отражается культурный разрыв между поколениями. С горечью, например, дед думает о том, какими странными и чужими являются имена его правнуков, о том, что холмы, низины, ямы Юлкотлинской степи имели свои собственные названия, которые мало кто помнит теперь.

Сопоставление прошлого и настоящего не только выявляет различие двух укладов жизни. Глубина нравственно-психологической дистанции, которая отделяет «отцов» и «детей», исключает возможность душевного контакта между ними. Символизация героев осуществляется путем их соотнесенности с этими двумя художественными полюсами произведения. Ценности предшествующего поколения, его опыт оказываются не нужными для решения новых исторических задач, поэтому не могут быть переданы внукам и правнукам, отказавшимся от общенародных религиозно-нравственных традиций, общего с народом бытового уклада. Жизнь потомков складывается иначе, и духовному содержанию жизни Миннибая и Акэби в ней нет места. Ярким тому подтверждением становится история невысказанного Акэби завещания своим детям.

Акэби репрезентирует архетип матери во всей его феноменологической целостности: «С этим архетипом ассоциируются такие качества, как материнская забота и сочувствие; магическая власть женщины; мудрость и духовное возвышение, превосходящее пределы разума; любой полезный инстинкт или порыв; все, что отличается добротой, заботливостью или поддержкой и способствует росту и плодородию» (Iung, 1996: 218). Архетипичность созданного А. Еники образа, по мнению М.И. Ибрагимова,

\footnotetext{
${ }^{7}$ «У очага могли находиться только хозяева жилища и уважаемые семьей гости, так как данная часть жилья имела сакральное значение. Согласно представлениям тюрков, только через огонь было возможно общение с божествами. Существовала строгая система запретов, связанная с поведением человека у очага. <..> Хозяева жилища строго соблюдали систему запретов, связанную с очагом, потому что от их поведения зависел весь порядок мироздания» (Dashkovskii, Karymova, 2012: 102).

${ }^{8}$ Огонь и очаг рассматриваются в тюркской этнографии и фольклористике как символы жизни и преемственности поколений (Dampilova, Naeva, 2010).

${ }^{9} \mathrm{~B}$ этом убеждении проявляется стратегия традиционного мироощущения, «продолжающего как тело, так и дом (а равно - жизнь, время, пространство) несколько далее физических очертаний» (Dashkovskii, Karymova, 2012: 102).
}

16

XLinguae Journal, Volume 10 Issue 1, January 2017, ISSN 1337-8384 
обнаруживается в частности в имени главной героини: «Выстроенный ряд: Akbikə - Aksylu - Akžingə - Akəbi - представляет собой стадии развития архетипа матери, итогом которого становится образ Акэби как выражение идеи “Великой Матери”». (Ibragimov, 2007: 224). Г. Халит утверждает: «Имеются важные обычаи и традиции, тесно связывающие сегодняшнее с прошедшим: любовь к народу, к родине, уважение младших к старшему поколению, считающему эту любовь святой. Вот эта идея <..> пронизывает рассказ Еникеева, является его лейтмотивом и как бы заостряет черты Акэби, превращая ее в обобщенный, в чем-то даже символический образ матери» (Khalit, 1985: 178).

Возвышение и сакрализация образа героини достигается с помощью различных приемов, выявляющих ее нравственную чистоту и высокую духовность. Значима символика белого цвета. Так, поэт, подолгу сидевший с умирающей Акэби и беседующий с ней, обращает внимание на семантику ее имени: «Акэби, Акэби! - тихо, будто разговаривает с самим собой, скандирует поэт. И вдруг спрашивает: - А почему Акэби, почему не Караэби? ${ }^{10}<\ldots>$ Значит, всю жизнь ты была белой. С белой, с чистой душой человек...» (Enikeev, 1974: 157-158). В мусульманской культуре белый цвет находится на вершине вертикальной иерархии ценностей, наделен универсальным и архетипическим значением. Установлено, что «концепт «ак» (белый) является одним из ключевых цветов концептуализации мира, во многих фразеологических единицах символизирует одну из противоположностей из ряда общечеловеческих ценностей: добра и зла, правды и лжи, социального верха и низа, поэтому существование его является основополагающим для категоризации и оценки явлений» (Sitdikova, 2013: 15-16).

В разговоре Акэби с поэтом рождается особое ценностное пространство, в котором раскрываются устойчивые константы человеческого существования: потребность во взаимопонимании, сочувствии, ответном душевном движении «другого», нормальных, естественных отношениях между людьми. У Акэби начинают дрожать губы, когда ее уже немолодой собеседник говорит о том, что мать нужна не только ребенку, но и человеку в любом возрасте. Эта психологическая деталь (дрожание губ) указывает не только на установившуюся между героями духовную близость, но и маркирует «пороговую», экзистенциальную ситуацию в их жизни.

В этом же ряду оказываются и портретные детали. На протяжении всего повествования акцентируется физическая немощь героини: она постепенно становится «бесплотной», «бестелой», «прозрачной», «легкой» и т.д. Эти портретные детали - своеобразные знаки преображения, освобождения от земной тяжести тела и перехода в иное состояние души, уже почти не обитающей в материально-физической сфере и пребывающей в возвышенной области чистой духовности.

Описание могилы Акэби на вершине горы, обращенной к берегам Белой и Дёмы, выдержано в сухом и сжатом стиле: «На высокой горе, над реками Белой и Демы, Акэби осталась одна» (Enikeev, 1974: 173). В отличие от образа степи в начале повести А. Еники строит целостную эпическую картину мира, возвышенно отрешенную от отдельной человеческой жизни и растворяющую ее в родовых началах бытия.

Наконец, в риторико-публицистической речи поэта на могиле Акэби выявляется национально-исторический масштаб ее жизни и судьбы: «Навсегда расстались мы с нашей матерью, с человеком белоснежной, чистой души... Да, да, она для всех нас была мамой. Мало того, я не колеблясь, назову ее святой

${ }^{10}$ Караэби - буквально: «черная бабашка».

17

XLinguae Journal, Volume 10 Issue 1, January 2017, ISSN 1337-8384 
матерью башкирского народа...» (Enikeev, 1974: 172). Надгробное слово поэта на могиле Акэби имеет программный характер. Его основная идея раскрывается в эстетическом движении от высокого торжественно-панегирического тона, восходящего к жанровой традиции мадхии ${ }^{11}$ с присущим ей типом лиризма надличным, растворенным в эмоциональной стихии высокого, к трагическому обобщению и пафосу отрицания, передающему личное отношение к происходящему. Герой выражает открытый протест против существующих в обществе законов и норм поведения, которые разъединяют людей, лишают их нравственных ориентиров, исключают из круга положительных культурных ценностей, делают «чужими» друг для друга.

Для Акэби высшая ценность - родная земля. В разговоре с поэтом она рассказывает о происхождении своего аула и его названия «Юлкотлы» «счастливая дорога». Она никогда не согласится с тем, чтобы забылась дорога, ведущая к родному порогу, к земле дедов и отцов: «Родина для нее - это родная земля. В этой земле лежат кости предков, на этой земле живут ее сверстники $<\ldots>$ разве может она их забыть, куда бы ни уехала, сколько бы ни прожила на свете» (Enikeev, 1974: 164). Эти размышления героини о родной земле и традициях, которые нельзя забывать, приобретают возвышенно-поэтическую абстрактность и обобщенность. Родная земля становится символом самых заветных чувств и наиболее высоких ценностей культуры.

Образ Акэби постепенно перерастает свои собственные рамки. Раздумья, переживания героини освобождаются от индивидуальной и социально-психологической определенности, становясь выражением общенародного миропонимания и мироотношения. С главной героиней, выступающей как хранительница духовных ценностей, связан апофеозный тон и высокий стиль, идущий от ориентации на эпическую традицию. В то же время в повесть входит «романное разноречие», связанное с воссозданием душевных процессов в их противоречивом динамическом единстве и отражающее разнородность национально-исторической жизни.

В отличие от эстетически одномерного, ориентированного на эпос характера Акэби образ поэта по-романному противоречив и разомкнут, лишен внутренней целостности и эпической завершенности. Однако неслучайно, что поэт, как, по сути, и Акэби, не имеет имени. Создавая образы этих персонажей, выступающих как хранители национальных традиций, писатель использует приемы максимально широкого обобщения, символизации, акцентирования в изображаемых характерах их типологически-родовой сущности, определяемой в одном случае архетипом матери, в другом - пророческой миссией поэта.

Примечательно, что поэт представлен в своей художественной безусловности, вне конкретных и специфицированных отношений, каких бы то ни было мотивирующих его поступки обстоятельств. Возможно, его особое состояние («трезв или пьян», «хмельной») - своеобразная форма «ухода» от действительности, демонстрация своей непричастности к социуму, переживающему нравственные изломы и испытывающему духовное оскудение. Обеспокоенность поэта тем, что забывается накопленное веками духовное богатство народа, дает основание предположить, что это и реакция на неспособность современной ему литературы выполнять свойственные ей

\footnotetext{
${ }^{11}$ Мадхия (с араб. - ода, хвалебное стихотворение, панегирик) - «жанр восточной поэзии; лирическое стихотворение, написанное в честь важного исторического события или какого-либо известного человека с перечислением и восхвалением его достоинств и заслуг» [Tatarskaia entsiklopediia, 2008: 16].
}

18

XLinguae Journal, Volume 10 Issue 1, January 2017, ISSN 1337-8384 
функции $^{12}$ сохранения и передачи культурного опыта, обеспечения непрерывности традиций в процессе национально-исторического развития.

С высоким стилем, возвышенно-патетическими интонациями сосуществует нейтральный, обыденно-разговорный, повествовательный тон, основная цель которого - выразить понимание современности как кризисного этапа национальной истории, характеризующегося выпадением целого поколения людей из единой мировой связи - обычаев, традиций, отношений, естественного порядка жизни, процессом, неизбежно сопровождающимся роковыми последствиями.

Содержание внутреннего мира матери, ее мечты и надежды, душевные устремления противопоставляются тому, что делают дети после ее смерти. Заветное желание матери - быть похороненной по мусульманским обычаям. Дети же решают муллу ${ }^{13}$ не звать, заупокойную молитву не читать. Вместо того, чтобы обернуть тело в пять слоев белым саваном, надевают одно из ее чистых платьев, вместо могилы с ляхетом ${ }^{14}$ кладут в маленький красный гроб. Для Акэби очень важно было оставить детям и внукам в память о себе дорогие ей вещи: это национальная башкирская одежда, сшитая из дорогого материала и украшенная шитьем, камнями, позументом и монетами, нагрудное украшение хаситэ, составленный из цветных камней и позолоченных монет, браслеты с бирюзой и яхонтом, бусы, накосники ${ }^{15}$. Это наследство дорого не по деньгам. Его ценность в другом: одежду и украшения необходимо беречь и хранить в память об отце и матери, о своем роде, как самые дорогие реликвии, а состарившись, передать последующим поколениям, поэтому некоторые вещи Акэби завещает поименно.

После смерти Акэби соседи, надеясь утешить детей в их скорби, отправили старый зеленый сундук в город. Он выглядит нелепо и жалко в городской квартире, уставленной современной мебелью. Но дочь Акэби хорошо помнила, какую важную роль сундук играл в жизни семьи, поэтому взволновалась и растерялась. Сундук как деталь интерьера, связанная со старинным укладом жизни, становится символом домовитости, основательности, самобытности уходящей в прошлое культуры быта.

А. Еники использует психологический прием умолчания, показывая реакцию детей, когда они открыли сундук и первое, что увидели, была лежащая сверху ткань для савана: «Увидев ее, не то что сказать что-нибудь, а посмотреть друг на друга не посмели, осторожно вынули и отложили в сторону» (Enikeev, 1974: 173). Что испытывают дети в этот момент? Запоздалое чувство вины? Стыд? В этих рефлексивных эмоциях проявляется суд совести - неприятие своего поступка, нарушающего этические нормы, самоосуждение. Психологическое состояние, вызванное этими чувствами, должно мотивировать дальнейшее поведение героев, гарантируя соблюдение нравственных норм и являясь признаком духовности в человеке. Однако в повести А. Еники между

\footnotetext{
${ }^{12}$ Исследователь арабо-мусульманской литературы Г.Э. фон Грюнебаум объясняет структурно-содержательное своеобразие восточной литературы тем, что «воображение, как таковое, и самовыражение не признавались целью литературы - ведь все доступное разуму и достойное его усилий уже ниспослано в Откровении или отчасти получено в результате рационального осмысления объективных данных; на творческие способности человека принято было смотреть пессимистически. < ..> Литературе помимо роли архива жизни общества надлежало выполнять двойную функцию - наставления и развлечения» (Griunebaum, 1981: 158-159).

${ }^{13}$ Мулла - служитель религиозного культа у мусульман.

${ }^{14}$ Лэхет - выемка в стенке могилы, куда кладут покойника и закрывают дощечками.

${ }^{15}$ Накосник (чэч-тебе) - полоска ткани, нашитая сверху монетами и бляхами, накладываемая сверху на косы.
} 
этической рефлексией и поступком отсутствует прямая зависимость, суд совести перестал выполнять этико-регулятивную функцию. Зять предложил сдать все содержимое сундука в гардероб театра, дочь и сын после некоторых колебаний согласились с этим предложением.

Из всех вещей, находящихся в сундуке, всех сразу заинтересовала «камчы» ${ }^{16}$ : «... это была отцовская камча, с которой он не расставался в молодости. С короткой ручкой, с бахромой из кожи, она была о трех концах, все с серебряными наконечниками» (Enikeev, 1974: 174). Суфиян вспомнил, что это нагайка отца, с которой он ходил на охоту. Даже зять с восхищением произнес: «Да-а, вот это реликвия! - воскликнул зять. - Но кто сбережет еe?» (Enikeev, 1974: 174). Суфиян торжественно вручил ее сыну Геннадию: «Возьми, сынок Гена, возьми эту дедовскую камчу... И помни, она была в руках Шаяхметовых!..» (Enikeev, 1974: 174).

Старинная башкирская одежда и украшения утрачивают национальнокультурную ценность и воспринимаются только с функциональнопрагматической точки зрения: « «Однако что им делать с этим джиляном, с нашитыми на нем бляхами, с этим бархатным камзолом, с хаситэ, кашмау ${ }^{17}$ или накосником?..» (Enikeev, 1974: 174). Примечательно, что находит своего владельца лишь родовая отцовская нагайка, которая применялась во время

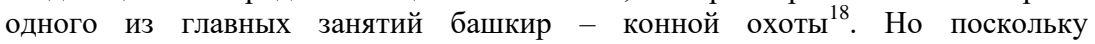
традиционное для башкирского народа назначение нагайки оказывается невостребованным в современной городской жизни, то происходит еe распредмечивание и семиотизация. По мнению Г.Х. Зиннатуллиной, картина «торжественной» передачи нагайки («символа силы и независимости башкирского народа») в руки внука символизирует противостояние вековых национальных традиций и мировоззрения нового поколения (Zinnatullina, 2010: 415).

Два символических предмета из зеленого сундука все же сохраняются - женское украшение (две больших чулпы ${ }^{19}$ из ажурного серебра с красным яхонтом посередине), которое Гульбика решила оставить себе как память о матери, и нагайка - патриархальный родовой символ Шаяхметовых. Но чулпы предназначались все-таки не для дочери, а для внучки: Акэби в разговоре с Гузель обещала ей «прислать» специально приготовленный для нее подарок. Нагайка, предмет, у которого было прямое назначение в старом укладе жизни, в завещании матери никак не упоминается, но вызывает всеобщий интерес и достается внуку Геннадию. Он как-то приезжал в Юлкотлы повидать бабушку. Геннадий не понимал ни слова из того, что она ему говорила, но смотрел на нее с доброй улыбкой, кивал головой, боясь обидеть. Акэби с грустью думала: «... что ни говори, в этом рыжеволосом парне и в самом деле текла ее кровь, башкирская кровь!» (Enikeev, 1974: 144).

Примечательно, что именно в связи с нагайкой в устах сына и зятя возникают слова «сохранить», «память»: «Но кто сбережет ее?»; «... помни, она была в руках Шаяхметовых!..». Две вещи, символизирующие мужское и

\footnotetext{
${ }^{16}$ Камчы - нагайка, плётка.

${ }^{17}$ Кашмау — старинный женский головной убор.

${ }^{18}$ «Традиция конной охоты на волков и лисиц, характерная для многих кочевых племен и народов Великого пояса степей, встречалась и у башкир Заволжья. Выезд на охоту осуществлялся в полном боевом снаряжении, в комплектацию которого входили массивная булава, плеть - нагайка (камсы), луки и стрелы» (Mannapov, 2009: 18). Универсальная для разных культур функция плетки - средство принуждения, инструмент индивидуального наказания (см.: Bertram, 992).

${ }^{19}$ Чулпы - лента с монетами и бляхами, которую женщины вплетали в косы. 
женское начало, остаются в семье Шаяхметовых. Память о народной культуре, питаемой природной степной жизнью, старым укладом и идентифицирующей национальной традицией, не утрачивается окончательно, несмотря на трагический разрыв между поколениями, но проявляется в обедненном и искаженном виде. Тем не менее в этом порыве - оставить у себя хотя бы две вещи в память об отце и матери выражается бесконтрольное действие глубинных сил души, противостоящих охватившим национальный мир процессам дезинтеграции и разобщения.

В разговоре с поэтом Акэби подчеркивает сохраняющую функцию коллективной народной памяти: «... Народное останется при народе, даст Бог, не исчезнет!» (Enikeev, 1974: 159). В этом же контексте звучат и слова Миннибая о том, что Акбикэ-килен не умерла, должна обязательно вернуться, и необходимо поддерживать огонь в ее очаге. Эпически завершенный народнопоэтический мир внутри себя преемствен и потому бессмертен. Цикличности и гармоничности этого мира, его неизменности и вечности противопоставлено динамичное линейное время, в котором живет поколение «детей»: «Проходили дни. Горе, как утренний туман, быстро развеялось. Полная труда и хлопот вольная, сытая жизнь катилась по старой колее. Для детей Акэби быстрый бег этой жизни был желанным и увлекательным» (Enikeev, 1974: 175). Создается образ времени, который символизирует и необратимое движение истории, развитие цивилизации, путь прогресса, и всевластную силу, подчиняющую жизнь человека своему ритму и управляющему его судьбой.

Итак, синтез конкретно-исторической определенности и масштабности бытийных прозрений автора и героев высвечивает разрушительные явления современной писателю действительности. Забвение традиций, своих истоков и родовых корней, с точки зрения автора, является национальным бедствием.

\section{Заключение}

Мотивы, повторяющиеся в данном произведении, образуют антитезы: жизнь - смерть, память - забвение, прошлое - настоящее, город - деревня, дом - дорога. Особенно значимы образы-символы «домашнего очага», «степи» и «родной земли». Могут быть отмечены определенная ритмичность в их повторении, а также тенденция, ведущая к их концентрации в своеобразные «стихотворения в прозе», связанные с идеями и образами других произведений А. Еники («Кто пел?» (1956) «Глядя на горы» (1948), «Родная земля» (1959), «Красота» (1964) и др.). Эти образы и мотивы формируют картину мира, на одном полюсе которой оказываются люди, в жизнь которых вместе с этими вечными ценностями входит высший смысл бытия, на втором - те, кто отчужден от них, внутренне не причастен к этому «кругообразному» процессу внеличного национально-исторического становления. Эта антитеза, аксиологически ориентированная, выявляет духовную глубину и значительность внутренней жизни представителей старшего поколения - с одной стороны, и несостоятельность существующих в современном писателю обществе жизненных норм и форм сознания - с другой.

Сюжетная организация произведения, судьба главной героини, система символических образов, взаимодействие слова повествователя и речи персонажей создают глубоко драматическую картину национального бытия. Писатель рисует кризисное состояние современного ему общества и разрыв естественной связи поколений, которыми он сопровождается. Противопоставление мира матери образу жизни детей как двух типов культур и соответствующих им «языков», не объединенных в духовную целостность национально-исторической жизни, приобретает символический смысл и 
становится выражением своего рода авторской философии жизни. Своеобразие проявления действующей в повести «Невысказанное завещание» символизирующей тенденции определяется особенностями авторской позиции, ее открытой публицистичностью, целеустремленностью, гражданственностью. Этой позиции соответствуют принципы типизации, основанные на взаимодействии фабульно-психологических и лирико-философских начал.

Семантическая структура символических образов и мотивов основана не на идеи двоемирия, а на осмыслении современности как времени утраты этнической идентичности. Символический подтекст произведения обнажает родовые категории человеческого существования, которые проецируются на психологические и бытовые реалии сюжета, наполняя их универсальным содержанием. Принципы символической типизации обогащают возможности реалистического изображения мира и человека, характеризуя одну из важнейших тенденций национального историко-литературного процесса.

\section{Bibliograpic references}

AMINEVA, V. R. 2010. Tipy dialogicheskikh otnoshenii mezhdu natsional'nymi literaturami (na materiale proizvedenii russkikh pisatelei vtoroi poloviny XIX v. i tatarskikh prozaikov pervoi treti XX v.). Kazan': Kazan. gos. un-t. 476 p. ISBN 978-598180-809-8.

AMINEVA, V. R. 2014. «Universal» and «Unique» as the Categories of Comparative Literature. Middle-East Journal of Scientific Research, n. 20 (12), pp. 2094-2098. ISSN 1990-9233

AMINEVA, V. R. 2015. Phenomenon of border in interliterary dialogues. Journal of language and literature (JLL), vol. 6, n. 2, pp. 246-249. ISSN 2078-0303

AVERINTSEV, S. S., FRANK-KAMENSKII I. G., FREIDENBERG O. M. 2001. Ot slova k smyslu: Problemy tropogeneza. M.: URSS. 121 p. ISBN 5-8360-0231-2

BERTRAM, D. G. 1992. Istoriia rozgi. M.: Prosvet. T.1. 288 p. ISBN 5-86068-010-4

BIROVA, J. 2013. About Theoretical Definitions of Pluralistic and Pluricultural Approaches. In: XLinguae, European Scientific Language Journal, vol. 6, issue 2, 2013, pp. 91-103. ISSN 1337-8384

BIROVA, J. 2013. Pluralistic and pluricultural approaches intuitively applied by teachers of French. In: XLinguae, vol. 6, issue 3, pp. 76-100. ISSN 1337-8384

Chinese Texts and Philosophical Contexts. 1991. 334 p. ISSN 559-0593

DAMPILOVA, L.S. - NAEVA, A.I. 2010. Simvolika ognia v tiurko-mongol'skoi fol'kloristike. Mir nauki, kul'tury, obrazovaniia, n. 4 (23), pp. 28-30. ISSN 1991-5497

DASHKOVSKII, P. K. - KARYMOVA, S. M. 2012. Veshch' v traditsionnoi kul'ture narodov tsentral'noi Azii: filosofsko-kul'turologicheskoe issledovanie. Barnaul: Altaiskii gosudarstvennyi universitet. 252 p. ISBN 978-5-7904-1218-9

DAUD, VAN. 2000. Ta'dib al-Attasa kak istinnoe i kompleksnoe obrazovanie $\mathrm{v}$ islame. Sravnitel'naia filosofiia. M.: Vostochnaia literatura, pp. 262-273. ISBN 5-02018404-7

DAVIDSON, O. M. 2013. Comparative literature and classical Persian poetics. Boston. 126 p. ISBN 9780674073203

DOUGLAS, W. B. 2007. National identity and globalization: youth, state, and society in post-Soviet Eurasia. Cambridge; New York: Cambridge University Press. 225 p. ISBN 0521699630, ISBN 13: 9780521699631

EFREMOVA, N. V. 2001. Problema bessmertiia v filosofii klassicheskogo islama. Universalii vostochnykh kul'tur. M.: Vostochnaia literatura, pp. 180-198. ISBN 5-02018233-8

ENIKEEV, A. N. 1974. Gliadia na gory. Povest' i rasskazy. Perevod s tatarskogo. M.: Sovremennik. 380 p. 
G.Tukay's poetry: the aspects of national identity / V.R. Amineva, M.I. Ibragimov, E.F. Nagumanova, A.Z. Khabibullina. 2015. Linguae European Scientific Language Journal, vol. 8, issue 1, pp. 79-87. ISSN 1337-8384

GRIUNEBAUM, G. E. fon. 1981.Osnovnye cherty arabo-musul'manskoi kul'tury. M.: Nauka. Gl. red. vostochnoi literatury. 227 p.

GUTMAN, E. V. - MASALIMOVA, A. R. - SHAIDULLINA, A. R. - NIZAMIEVA, A. M. - MUKHAMADIEVA, A. H. (2014). Foreign language discipline integrative potential in the students' research competence development. American Journal of Applied Sciences, 11, 1099-1103.

IBRAGIMOV, M. I. 2003. Mif v tatarskoi literature XX v.: problemy poetiki. Kazan': Gumanitarya. $63 \mathrm{p}$.

IBRAGIMOV, M. I. 2007. «Natsional'naia literatura» i sovremennye metody analiza (na primere tatarskoi literatury). Uchenye zapiski Kazanskogo gosudarstvennogo universiteta. T. 149. Seriia Gumanitarnye nauki. Kniga 2. Kazan', pp. 218-227. ISSN $1815-6126$

Identité littéraire de l'Europe, 2000. P.: P.U.F. 224 p.

IUNG, K. G. 1996. Dusha i mif: shest' arkhetipov / perevod s angliiskogo. Kiev: Gos. biblioteka Ukrainy dlia iunoshestva, 1996. 384 p. ISBN 5-7707-8958-1

JOHNSON, A. L. 1982. Jakobsonian Theory and Literary Semiotics: Toward a Generative Typology of the Text. New Literary History, vol. 14, n. 1, pp. 33-61. DOI: $10.2307 / 468956$

KHALIT, G. 1985. Portrety i problemy. Izbrannye stat'i raznykh let. Kazan': Tatarskoe knizhnoe izdatel'stvo. 344 p.

KHATIPOV, F. M. - SVERIGIN, R. KH. 2009. Amirkhan Eniki: zhiznennyi i tvorcheskii put' pisatelia: Monografiia. Kazan': TGGPU. 114 p. Na tatarskom iazyke. ISSN 978-5-87730-391-1

KRISTEVA, J. 1980. Desire in Language: A Semiotic Approach to Literature and Art. New York: Columbia University Press. 305 p. ISBN 0231048076; 9780231048071

LACAN, J. 1998. The Language of the Self: The Function of Language in Psychoanalysis. Trans, by Anthony Wilden. Baltimore. Johns Hopkins University Press. 368 p. ISBN 0801858178; 978-0801858178

LOSEV, A. F. 1976. Problema simvola i realisticheskoe iskusstvo. M.: Iskusstvo. 367 p.

LOTMAN, Iu. M. 1996. Vnutri mysliashchikh mirov. Chelovek - tekst - semiosfera istoriia. M.: Iaz. rus. kul'tury. 464 p. ISBN 5-7859-0006-8

MANNAPOV, M. M. 2009. Bashkiry Stepnogo Zavolzh'ia (istoriia rasseleniia, rodoplemennaia struktura, khoziaistvo). Avtoref. ... kand. ist. nauk. Ufa. 23 p.

MASALIMOVA, A. R. - IKRAMOVA, G. D. - SHAIDULlinA, A. R. GUBAIDULLINA, G. T. - APRAKSINA, N. D. (2014). Distant in-company foreign language learning involving university student-tutors. American Journal of Applied Sciences, 11, 1123-1127.

MASAliMOVA, A. R. - PORCHESKU, G. V. - LIAKHNOVITCH, T. L. (2016). Linguistic Foundation of Foreign Language Listening Comprehension. International Electronic Journal of Mathematics Education, 11(1), 123-131.

MELETINSKII, E. M. 2000. Poetika mifa. M.: Vostochnaia literatura. 406 p. ISBN 502-017878-0

MINER, E. 1990. Comparative Poetics: An Intercultural Essay on Theories of Literature. Princeton, New Jersey. 259 p. ISBN 9780691014906

ROSSE, R. 1962. Symbols and civilization: Science, morals, religion, art. N.-Y.: Harbinger book, $243 \mathrm{p}$. 
SAIAPOVA, A. M. 2006. Dardmend i problema simvolizma v tatarskoi literature. Kazan': Alma-Lit. 246 p. ISBN 5-87-730-100-7

SITDIKOVA, A. F. 2013. Kognitivnoe issledovanie tsvetovogo prostranstva v tatarskom iazyke. Avtoref. ... kand. filol. nauk. Kazan'. 22 p.

SHAIDULLINA, A. R. - EVSYUKOVA, N. Y. - MIKHAILOV, V. A. GAZIZOVA, F. S. - MASALIMOVA, A. R. - KHAIRULLINA, E. R. GALIMZYANOVA, I. I. (2015). The Curriculum Project on Professional and Pedagogical Teachers? Communication Culture Formation. Mediterranean Journal of Social Sciences, 6(2 S3), 202-208.

SKORUPSKI, J. 1983. Symbol and theory. Cambridge. 265 p. ISBN 0521272521; 9780521272520

ŠKULJ, J. 2003. Comparative literature and cultural identity. Comparative Literature and comparative Cultural Studies. Purdue University Press, pp. 142-151. ISBN 1557532907; 9781557532909

SMIRNOV, A. V. 2001. Logika smysla: Teoriia i ee prilozhenie k analizu klassicheskoi arabskoi filosofii i kul'tury. M.: Iaz. slavian. kul'tury. 504 p. ISBN 594457-004-0

SHUKUROV, SH. 1989. Ob izobrazhenii proroka Mukhammada i probleme sokrytiia Lika v srednevekovoi kul'ture islama. Sufizm v kontekste musul'manskoi kul'tury. M.: Nauka. Gl. red. vost. lit-ry, pp. 252-267. ISBN 5-02-016695-2

STORR, A. 1987. Symbols of unity and integration. Symbols in life and art / Ed. by J.A. Leith. C: McGill-queen's university press, pp. 17-30. ISBN 9780773506169

SVAS'IAN, K. A. 1980. Problema simvola v sovremennoi filosofii: (Kritika i analiz). Erevan: Izd-vo AN ArmSSR. 226 p.

Tatarskaia entsiklopediia: V 6 t. 2008. Kazan': Institut tatarskoi entsiklopedii AN RT, T. 4.: M-P. 768 p. ISBN 978-5-902375-05-0

TOPOROV, V. N. 1996. Mif Ritual. Simvol. Obraz: Issledovaniia v oblasti mifopoeticheskogo: Izbrannoe. M.: Progress. Kul'tura. 623 p. ISBN 5-01-003942-7

WAARDENBURG, J. 1980. Symbolic aspects of myth. Myth, symbol and reality. Notre Dame L., pp. 41-62. ISBN 0268013497; 978-0268013493

World Philosophy. A Text with Readings. 1995. New York, 399 p.

ZAGIDULLINA, D. F. 2015. Tatarskaia literatura 1960-1980 gg.: avangardnye poiski i eksperimenty. Kazan': Tatarskoe knizhnoe izdatel'stvo. 383 p. Na tatarskom iazyke. ISSN 978-5-298-02902-5

ZAGIDULliNA, D. - AMINEVA, V. 2016. Avant-Garde Research in the Field of Verse Forms (based on I. Yuzeev lyrics). XLinguae European Scientific Language Journal, vol. 9, issue 1, pp. 135-145. ISSN 1337-8384.

ZINNATULLINA， G. KH. 2010. Stilisticheskie osobennosti literaturnykh antroponimov. Vestnik Nizhegorodskogo universiteta im. N.I. Lobachevskogo, n. 3 (1), pp. 410-417. ISSN 1993-1778

Работа выполнена при финансовой поддержке РГНФ.

Words: 5366

Characters: 41662 (23,14 standard pages)

Assoc. Prof. Venera R. Amineva, Doctor of Philology

Department of Russian and foreign literature

Kazan Federal University

18, Kremlyovskaya St., 420008 Kazan

Republic of Tatarstan, Russia

amineva1000@list.ru 